\title{
Historical Trajectories of Disaster Risk in Dominica
}

\author{
Jenni Barclay $^{1} \cdot$ Emily Wilkinson $^{2} \cdot$ Carole S. White $^{3} \cdot$ Clare Shelton $^{3}$. \\ Johanna Forster ${ }^{3} \cdot$ Roger Few $^{3} \cdot$ Irene Lorenzoni $^{1} \cdot$ George Woolhouse $^{4}$. \\ Claire Jowitt $^{5} \cdot$ Harriette Stone $^{6} \cdot$ Lennox Honychurch $^{7}$
}

\begin{abstract}
The calamitous consequences of 2017 Hurricane Maria for the Caribbean island of Dominica highlighted the acute and increasing susceptibility of the region to disasters. Despite increasing international attention to disaster risk reduction, recovery from hazard events can be especially lengthy and difficult for small island developing states. In this article, we build on existing understandings of disaster risk as a physical and social condition, showing that historical processes are fundamental to understanding how conditions of risk emerge and persist over time. We take an integrated approach to analyzing the drivers of risk accumulation, using the example of Dominica, where processes set in motion during the colonial period have shaped the location of people and assets, the degree to which they might be harmed, the societal repercussions of that harm and the prospects for recovery. We focus on the underlying economic vulnerabilities and physical exposure to hazards created by agricultural, economic, and social
\end{abstract}

Jenni Barclay

J.Barclay@uea.ac.uk

1 School of Environmental Sciences, University of East Anglia, Norwich NR4 7TJ, UK

2 Overseas Development Institute, London SE1 8NJ, UK

3 School of International Development, University of East Anglia, Norwich NR4 7TJ, UK

4 Civil Engineering and Environmental Hydraulics, HR Wallingford, Howbery Park, Wallingford OX10 8BA, UK

5 School of History, University of East Anglia, Norwich NR4 7TJ, UK

6 Civil, Environmental and Geomatic Engineering, University College London, London WC1E 6BT, UK

7 University of the West Indies, Open Campus Dominica, Roseau, Dominica practices, and successive disaster responses that have constrained recovery. Uncovering these historical drivers and persistent issues, elucidates lessons for pursuing a more resilient development trajectory, including through the promotion of economic restructuring and diversification, and land reform.

Keywords Dominica - Historical trajectories - Natural hazards $\cdot$ Resilience $\cdot$ Risk exposure $\cdot$ Small island developing states

\section{Introduction}

On 18 September 2017 Hurricane Maria, a category 5 hurricane, swept across the Caribbean island of Dominica. Its passage left catastrophic destruction in its wake- $80 \%$ of the population was affected and more than $90 \%$ of buildings were damaged or destroyed-as well as 31 people dead and 37 missing (ACAPS 2018). This disaster occurred just two years after 2015 Tropical Storm Erika, which was categorized as a less intense storm but resulted in 11 fatalities, 22 people missing, and approximately $10 \%$ of the population was affected (Government of the Commonwealth of Dominica 2015). Recent disasters have also imposed significant costs on the Dominica economy, leading to major declines in GDP growth: 2007 Hurricane Dean resulted in damage equivalent to $58 \%$ of GDP; Tropical Storm Erika resulted in damage equivalent to $90 \%$ of GDP; and for Hurricane Maria total loss and damage has been estimated to be $224 \%$ of GDP (Government of the Commonwealth of Dominica 2015; ACAPS 2018). The impacts of these intense storms were disastrous; but as with all disasters, the drivers of risk are social, political, and cultural, as well as physical. Across the Caribbean, a series 
of shortsighted policy and investment decisions have led to an accumulation of exposure and vulnerability to hazards in these islands. High levels of debt and dependency on external finance, economic instability, insularity, remoteness, and environmental fragility limit the development potential of small Caribbean islands, as do the repeated and devastating impacts of disasters (Wilkinson et al. 2016). As Benson et al. (2001) note in a report on the economic impacts of contemporary disasters in Dominica, some sectors and subsectors are more vulnerable to hazards than others and measures can be taken to reduce the vulnerability of the Dominica economy and thus contribute to sustainable growth.

Hurricane Maria was one of a long succession of hazard events that have impacted Dominica, with effects that can be traced, at least in part, to actions and processes rooted in colonial and postcolonial history. An historical analysis can help to reveal the reasons why risk has been allowed to accumulate (and where exposure has been successfully dealt with). We argue that by the time of independence on 3 November 1978, Dominica was already on a development trajectory of high exposure and economic vulnerability that was difficult to alter. This article sheds light on these historical events to help explain why Dominica faces significant challenges in pursuing social, economic, and sustainable development after Hurricane Maria.

\section{Dominica: The Context}

The Caribbean island of Dominica (capital city: Roseau) occupies around $750 \mathrm{~km}^{2}$ of land. The highest elevation is Morne Diablotins (1447 m), part of a chain of rainforestcovered volcanic peaks that creates a central, steeply dissected mountain range, from which 365 rivers originate (Fig. 1). This precipitous topography creates unstable slopes, strong orographic variation in rainfall and a steep marine shelf. At $15^{\circ} 18^{\prime} \mathrm{N}$ and $61^{\circ} 23^{\prime} \mathrm{W}$ (Roseau), Dominica also lies under the influence of the intertropical convergence zone, with a shift in wind patterns and broadly increased rainfall during the July to October hurricane season.

Consequently, and in common with many other Small Island Developing States (SIDS) worldwide, Dominica is prone to a wide variety of natural hazards, including hurricanes, intense rainfall, slope instability, volcanic eruptions, seismic activities, and tsunamis (Wilkinson et al. 2016). Since Columbus's ship first encountered the island in 1493, impacts from some 177 intense storms or hurricanes, and four earthquakes or earthquake swarms have been recorded (Table 1). About $70 \%$ of the island's total land base is unsuitable for modern agriculture, primarily due to the risk of sheet erosion or waterlogging (Burke and Lovell 2000).

Decisions taken by the colonial powers (by the French and then the British) have played a significant role in shaping population distribution and growth patterns, land use, and recovery from hazardous events (Tables 1 and 2). Historians infer that the pre-Columbian (Kalinago) population lived mainly in small dispersed settlements, close to fertile land and relatively sheltered from hazards (Burke and Lovell 2000), locations that would also have afforded better protection from hurricanes (Schwartz 2015). French and English occupation, however, shifted settlements to locations with good external trading routes and strategic and defensive advantages.

The critical moments of relevance to hazard exposure in Dominica's history are summarized in Table 2. Dominica officially remained a neutral territory until the Treaty of Paris in 1763, after which the land was ceded to Britain, surveyed and a map produced-the Byres Map (Byres 1776). The revenue from selling off parcels of land was retained by the British Crown and not reinvested in Dominica; it was expected that profit and capital growth from land use would drive investment in the island's infrastructure and economic development.

Under British rule, the economic history of Dominica was characterized by an economically dominant export crop of one kind or another (Yankey 1969, p. 138 quoted in Nelson 2010, p. 224). In this article we argue that the impacts of hazards, diseases, and other shocks on these dominant crops, alongside the land use and labor practices created by this economic model, have all contributed to Dominica's underdevelopment and high levels of disaster risk. Disease, natural hazards, and other economic stresses reduced employment opportunities, promoting a drift toward marginal settlement on Crown Land and on the edges of larger towns; and deficiencies in governance meant that insufficient action was taken to counteract these pressures. We therefore take an integrated approach to analyzing the historical, physical, social, and political drivers of risk accumulation, in order to understand the important consequent barriers to the reduction of risk. In the following sections, we develop an understanding of the historical factors that have shaped Dominica's development trajectory, focusing on the underlying economic vulnerabilities and physical exposure to hazards created by events and decisions taken during the colonial period, and their impact on post-disaster recovery.

This article follows a now well-established understanding of disaster risk as both a social and physical condition, in which the chances of being exposed to, and adversely affected by, hazards are generated at least in part by the decisions, actions, behaviors, and policies adopted by individuals and institutions, many of which have deep- 
Fig. 1 Topographic map of Dominica showing the capital city Roseau and other selected settlements, ports and airports, and main roads. The "King's

Three Chains" (Table 2) is not shown as it is only 66 yards or $60.35 \mathrm{~m}$ wide but follows entire coast. Source Caribbean Handbook on Risk Management (CHARIM) geonode for Dominica (http://charimgeonode.net/) and Reading (1986)

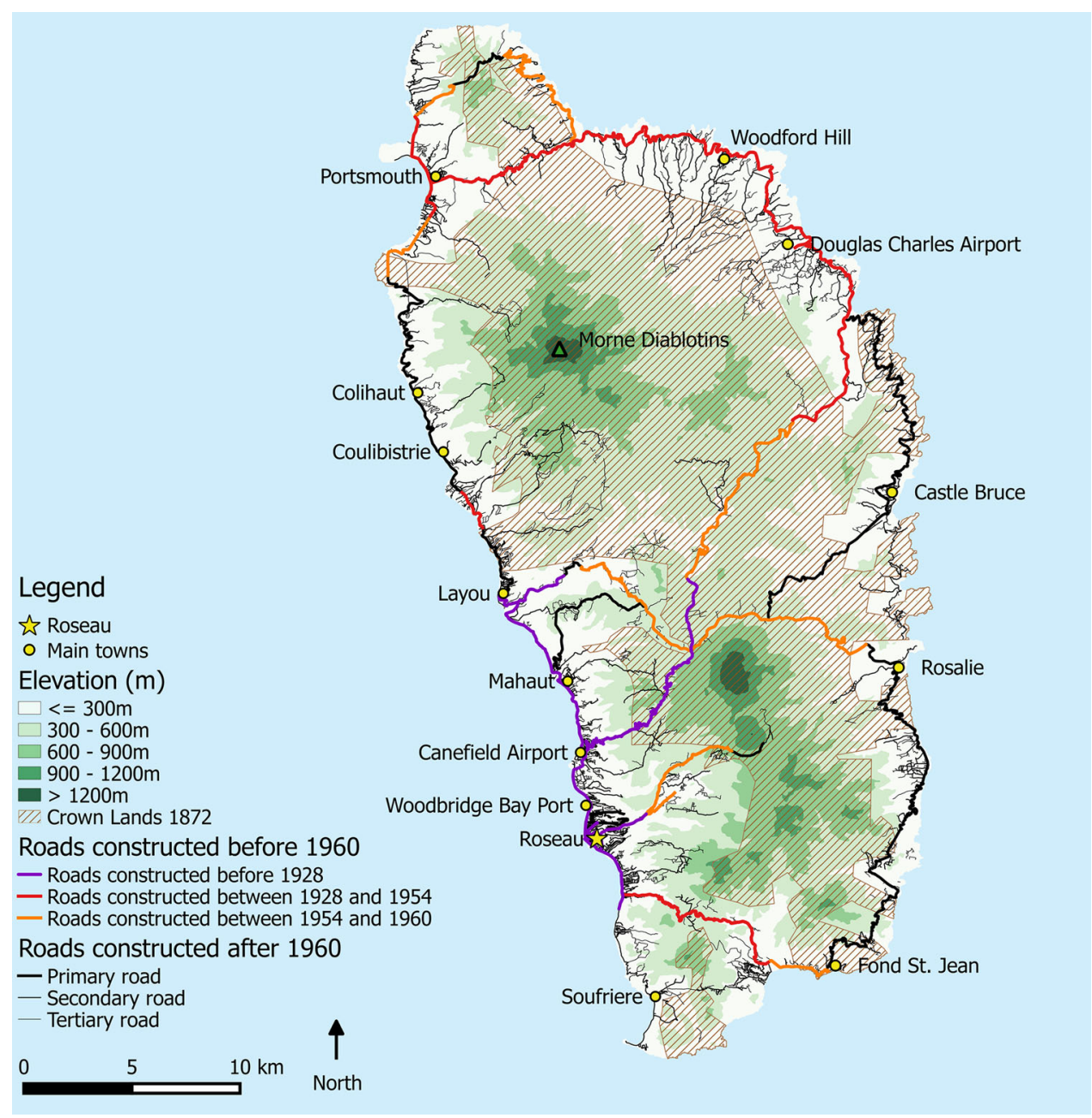

seated structural roots (see, for example, Hewitt 1983; Bankoff et al. 2004; Collins 2009). Contributions from a cross-disciplinary body of scholarship on disaster research have emphasized the importance of understanding how these structures and conditions emerge over time, and that many are the product, at least in part, of drivers set in train during colonial and postcolonial times (Pelling 2003; Wisner et al. 2004; Lewis and Kelman 2010). Relatively few studies, however, have concentrated their focus on these long-term historical roots of disaster risk. Work such as this that traces drivers of risk and their dynamics over periods of three centuries and more of historical influence remains rare. Notable exceptions include analyses of Peru's five-hundred-year earthquake (Oliver-Smith and Hoffman1999) and drivers of cyclone risk since the 17th century in the Mascarene Islands (Garnier and Desarthe 2013).

Much of the broader scholarship on Caribbean development pathways elucidates how the colonial experience across various islands has been translated into contemporary patterns of economic, social, and political development (Mandle 1982; Bishop 2013; Dookeran 2015). We seek to extend that tradition of analysis more specifically to Caribbean disasters research, underlining that historical processes are fundamental to understanding not only how conditions of risk emerge, but also how societal inertia causes them to persist over time. Using the example of Dominica, we demonstrate how processes much earlier than independence in 1978 have shaped where people and assets are located, the degree to which they might be harmed, the societal repercussions of that harm, and the prospects for recovery. We argue that uncovering these historical drivers and persistent issues also shows how they might be avoided to improve the likelihood of progress towards resilient development, particularly at a time when Dominica is engaged in development programs aimed at "building back better." 


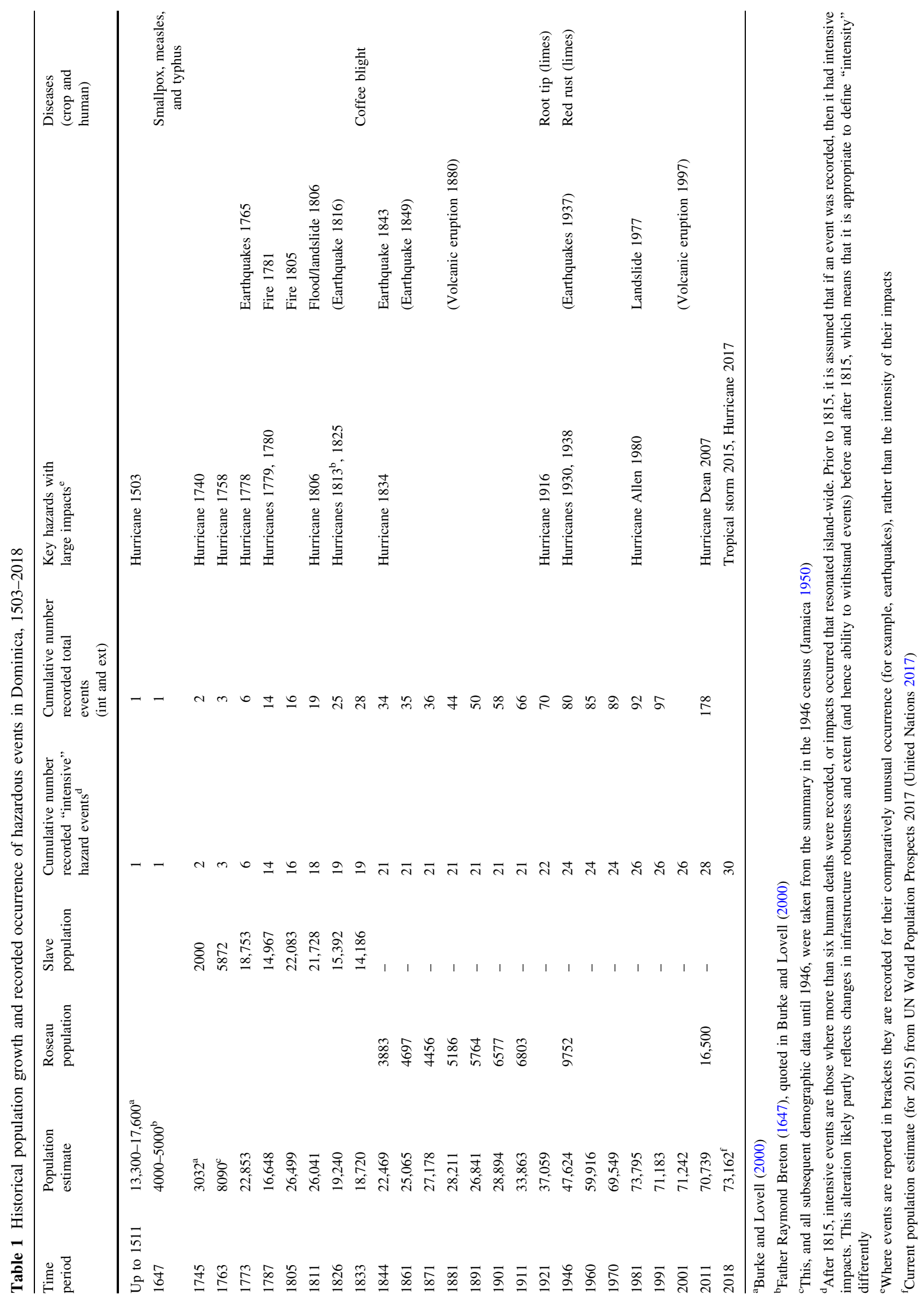




\section{Methodology}

While there is no direct causal link between decisions taken more than 200 years ago and disaster impacts in Dominica today, historical analysis generates structural knowledge about disaster risk and helps to identify far-reaching and long-term societal mechanisms, specific types of processes and recurrent structures for dealing with disaster (Schenk 2015). The analysis of decisions taken over a long period of time with regard to labor, land use, the market economy, and disaster recovery, contributes to our understanding of present conditions of risk. Data were collected and analyzed by a multidisciplinary team of social and physical scientists with expertise in disaster and climate risk governance; geological hazards and interdisciplinary approaches to risk reduction; vulnerability and adaptation to environmental hazards and climate change; and colonial and maritime history and cultural encounter. Specialized disciplinary teams focused on political, social, and economic themes over three time periods (1627-1783; 1813-1838; and 1945-1979) and on physical events (which spanned the entire historical, and where possible, prehistorical record). Research drew on both primary and secondary data sources, using material from historical archives and contemporary literature databases. Historical data were obtained through archival research in the UK (predominantly from The British Library collections and The National Archives) and Dominica (from The National Archives Unit) between November 2016 and July 2017, in addition to an extensive web-based search of peer reviewed and grey literature. Where possible, researchers consulted original sources such as parliamentary papers and records, contextualized with relevant critical sources from the historiography of Dominica. The research team then compared key moments for each of the themes and identified the decisions taken around land use and agriculture, land tenure, capital investments, post-disaster aid, and the Caribbean development priorities for colonial governments. These decisions elucidated best the influence of early decision making and colonial governance on current decision making (global and local) and land occupancy patterns relevant to disaster risk reduction. This complexity is best illustrated through a case study and we chose recovery from the hurricane of 1834 as a pivotal event, representing a disaster in the middle of the colonial times, when recovery coincided with other important social and economic changes linked to emancipation. Findings from this research were shared and verified through a series of discussions with local historians, academics, and disaster risk stakeholders during a visit to Dominica in March 2017. Further demographic, economic, and agricultural data were then synthesized to provide a more complete record of population growth and development activities during the study period (1627-present).

\section{Disaster Risk Accumulation in Dominica}

In the following section we focus on the differing drivers that contributed towards the accumulation of vulnerabilities to future hazardous events in Dominica. These drivers both influence the outcomes of contemporary hazardous events and drive decision making that amplifies the impacts of future events. We provide a synoptic account of each of these historical drivers (underlying economic vulnerability, social and cultural drivers that increased exposure to risk, and weak governance and disaster response) while also using the case study of response to the 1834 hurricane to exemplify the interaction between these elements.

\subsection{Underlying Economic Vulnerability}

The history of Dominica since the late 17th century was characterized by successive (failed) attempts by the British colonial powers to establish dominant large-scale agricultural production that would provide income for the colony and home nation and enable the island to flourish (summarized in Table 2). During the colonial period, despite various thwarted attempts to rectify the situation, the island's economy remained structurally weak with low levels of productivity, and high susceptibility to external economic shocks and hazards. Decisions taken regarding land ownership and agricultural and road infrastructure investments deepened this underlying economic vulnerability.

Dominica was ceded to the British by the French in 1763 and, at that point, grouped administratively with other Caribbean Islands (and regrouped again in 1871, Table 2). The "ceded" islands (Dominica, St. Vincent and the Grenadines, Grenada and Tobago) were geographically and culturally distinctive and physically well dispersed from one another and other colonized Caribbean territories at that time (for example, Barbados, St. Lucia, St. Kitts and Nevis, Antigua and Montserrat). Correspondence through this time period demonstrates the uneasy "fit" the local legislature felt with being in this grouping (Hamilton 1894; Naftel 1898). Yet, the remote colonial system of governance meant that a homogenous approach to development was often adopted across islands, despite particular recommendations generated by locally and regionally commissioned reports (Table 2). Typically, when an approach appeared to generate income in one place, the approach was modified for all, rather than considering the distinctive geographical, resource, and social opportunities represented by each island. 
Table 2 Historical developments and policies concerning land use, infrastructural development, governance, and social attitudes in Dominica, $1627-1978$

\begin{tabular}{|c|c|c|}
\hline Time & Events and Policies & Sources \\
\hline 1627 & $\begin{array}{l}\text { Dominica is a Kalinago stronghold and base from which to launch attacks on } \\
\text { European colonists }\end{array}$ & Honychurch (1995) \\
\hline $1686-1763$ & $\begin{array}{l}\text { Following continued battles for control between the British, French, and } \\
\text { Kalinagos, Dominica is declared neutral territory. The French develop } \\
\text { coffee and cocoa plantations, with some English habitation }\end{array}$ & Honychurch (2017), Murdoch (1984) \\
\hline 1763 & $\begin{array}{l}\text { Dominica ceded to Britain by the Treaty of Paris after the 7-year war } \\
\text { (1756-1763) }\end{array}$ & Murdoch (1984) \\
\hline $1763-1778$ & $\begin{array}{l}\text { UK surveying (Byres Map) and selling of land, generating revenue of } \\
£ 312,09211 \mathrm{~s} 1 \mathrm{~d} \text {. Payments were by installment and deposit, instantly } \\
\text { creating indebtedness and payment default. New landowners escalate } \\
\text { importation and use of slaves and plantations. UK investment focusses on } \\
\text { defense and market trading: a coastal-strip was created as the "King's } \\
\text { Three Chains" - reserved for Government Buildings and an ideal trading } \\
\text { harbor, Portsmouth designed and laid out as the capital of Dominica but } \\
\text { thwarted by insect-borne disease bred in swamps }\end{array}$ & $\begin{array}{l}\text { Honychurch (1995, 2017), Murdoch (1984), } \\
\text { Niddrie (1966), Byres (1776) }\end{array}$ \\
\hline $1778-1783$ & French colonial rule & \\
\hline $1783-1832$ & $\begin{array}{l}\text { Return to British rule by the Treaty of Versailles (as part of the Windward } \\
\text { Islands). Continued focus on defensive infrastructure and increasing } \\
\text { maroonage: slaves that use mountainous interior to hide and subsist. This } \\
\text { culminates in the Maroon Wars (1812-1815), punctuated by further } \\
\text { hurricane activity (Table 1) }\end{array}$ & $\begin{array}{l}\text { Honychurch (1995, 2017), Welch (1968), House of } \\
\text { Commons (1815), Trouillot (1988) }\end{array}$ \\
\hline $1833-1838$ & $\begin{array}{l}\text { Abolition of Slavery Act (1833) leads to full emancipation (1838) following } \\
\text { period of "apprenticeship." Poverty amplified by hurricane and coffee } \\
\text { blight (Table 1) and land-use practice }\end{array}$ & $\begin{array}{l}\text { Honychurch }(1995,2017), \text { West India Royal } \\
\text { Commission }(1898)\end{array}$ \\
\hline $1850-1892$ & $\begin{array}{l}\text { Dominica grouped in the Leeward Islands (1871). Local pull for economic } \\
\text { diversification on the island, combined with local evidence from Dr John } \\
\text { Imray encouraged lime cultivation, diversification further enhanced } \\
\text { development of Botanic Station (1884). Development hampered by lack of } \\
\text { investment in road infrastructure }\end{array}$ & $\begin{array}{l}\text { Honychurch (1995), Nicholls (1894), Hamilton } \\
\text { (1894), West India Royal Commission (1897) }\end{array}$ \\
\hline $1893-1898$ & $\begin{array}{l}\text { Three reports commissioned in response to poor economic performance and } \\
\text { poverty: (1) Royal Commission ("Hamilton" Report, 1894) "into the } \\
\text { condition and affairs of the island of Dominica"; (2) West India Royal } \\
\text { Commission (1898), analyzing the regional depression of the sugar } \\
\text { industry (report includes recommendations on growth of bananas and } \\
\text { limes, and infrastructure development); and (3) Naftel Report (1898), } \\
\text { commissioned by the local legislature, appraisal of island to attract } \\
\text { "capitalists and intending colonists" }\end{array}$ & $\begin{array}{l}\text { Hamilton (1894), West India Royal Commission } \\
\text { (1897), Naftel (1898) }\end{array}$ \\
\hline $1900-1938$ & $\begin{array}{l}\text { First World War-leads to drop in trade and increased price of food. Limited } \\
\text { export market for limes during depression/U.S. prohibition. Further } \\
\text { hurricanes and crop disease (Table 1) }\end{array}$ & \\
\hline $1938-1950$ & $\begin{array}{l}\text { Dominica moved to the Windward Islands Administrative Union. West India } \\
\text { Royal Commission (1938) to analyze regional social and economic } \\
\text { conditions (Moyne Commission). Action hampered by WWII, which also } \\
\text { reduced fishing due to hostile ships. Land purchase reform in favor of local } \\
\text { smallholders }\end{array}$ & West India Royal Commission (1945) \\
\hline 1950 & $\begin{array}{l}\text { Establishment of bananas as major crop (accounting for about } 80 \% \text { of all } \\
\text { exports by the 1960s) }\end{array}$ & \\
\hline $1955-1967$ & $\begin{array}{l}\text { Various developments in the island's governance system leading up to } \\
\text { independence. These include the introduction of the Ministerial system } \\
\text { (1955) and the granting of Associated Statehood in } 1967\end{array}$ & \\
\hline 1978 & $\begin{array}{l}\text { Full independence attained in November } 1978 \text { under a republican } \\
\text { constitution, based on the Westminster model. Strong hurricane in August } \\
1979 \text { (Table 1) }\end{array}$ & \\
\hline
\end{tabular}




\subsubsection{A Focus on Monocrops}

On Dominica a succession of coffee, sugar, cocoa, limes, and bananas dominated as the main export crop at any one time (Fig. 2a). Yet, the underlying assumption that investment and development on any island would follow from the profits from agriculture after land sales and redistribution in the late 18th century proved untrue in Dominica (Murdoch 1984; Trouillot 1988; Honychurch 2017). In 1894, an enquiry for the British government by Commissioner, Sir Robert Hamilton noted that "Dominica, though one of the most fertile of the British West Indian Islands, is [...] less developed [...] and its inhabitants appear less prosperous and contented" (Hamilton 1894, p. v). Figure $2 \mathrm{a}$ illustrates the variations in economic output for key crops for the period 1763-2016, as well as their association with key hazardous events and crop disease.

Coffee, attractive for the relatively small scale of investment in infrastructure needed and grown in the 18th century by French smallholders, was the principal export crop of Dominica until the 1830s, when a combination of factors-including the emigration of French landowners, deforestation, insect blight, a hurricane in 1834, and increasing sugar prices-signaled its decline. Requests for relief following the 1834 hurricane (House of Commons 1855) demonstrate the particular challenge associated with the dual threat of long regrowth time (4 years) and disease for the coffee bean growers in comparison to the largescale cane growers on neighboring islands. Sugarcane production (regrowth in 6-12 months) consequently increased (Fig. 2), but external political factors affected its viability as well as the challenges posed by infrastructural destruction caused by earthquakes and later hurricanes (Table 1). This mountainous island was late in its development of this previously lucrative crop: by 1854 , the Caribbean sugar crop was no longer protected by import duties in Britain, and by 1874 sugar was being traded on the free market (Fig. 2b). Cocoa temporarily filled the gap in exports until many trees were destroyed during the hurricanes of 1915 (minor) and 1916 (Nelson 2010). Although growing cocoa required a relatively small investment, this was offset by the long-term hurricane impact, as cocoa takes longer to regrow (3-5 years). Limes had been first explored as a possible alternative income source in 1860 due to the value of lime products and the diversity of markets for juice, oil, and extract. As sugar declined in value, growth was encouraged and peaked in the 1920s when lime accounted for over $80 \%$ of the island's total export value (Nelson 2010; Fig. 2a). However, disease, three hurricanes (1926, 1928 (smaller hurricanes), and 1930, Table 1) and a drop in lime market value during U.S. prohibition and the global recession saw the demise of lime production in Dominica (Fig. 2a). Bananas were next. A report by the West India Royal Commission (Morris 1897) had recommended Dominica establish fruit trade (bananas) with North America, emulating trade between Jamaica and New York. By 1953, this amounted to $45 \%$ of all export values, surpassing citrus (Trouillot 1988). Bananas, referred to as "green gold" by Thompson (1987), were the mainstay of Dominica's economy until the 1990s (Fig. 2a), when, coupled with sporadic impacts from hurricanes, preferential trade tariffs from the EU that had existed since independence came to an end (Payne 2006, 2008; Fig. 2a).

Thus, the rise and demise of each export crop was associated with a complex combination of disease, hazard, and economic circumstances, leading to an increase or drop in output. These factors often intersected cumulatively, threatening the long-term sustainability of each successive crop as a commercial enterprise. The cycle of rise and demise resulted from an economy dominated by monocultural agricultural practices on large plantation estates; but it was not uniformly encouraged. Various reports recommended alternative practices, but there were barriers to their implementation. By the end of the 19th century, the British colonial powers began to express concern about the island's economic productivity, along with broader concerns of maintaining production in the West Indies (Hamilton 1894; West India Royal Commission 1897). The overreliance on a few main crops for export and economic prosperity, alongside the subsistence economy, was questioned in Dominica as it was in other parts of the Caribbean (Barker 1993). Directed locally, the Hamilton (1894) and Naftel (1898) reports both recommended crop diversification and the encouragement of small landowners and laborers to produce more than "provisions" (subsistence crops). Dominica's mountainous terrain had posed systematic challenges to agricultural development throughout the colonial period. Significant infrastructural investment was needed to unlock the agricultural potential of the interior at any scale. However, land purchase and ownership arrangements severely restricted this investment and the encouragement of crop diversification. These arrangements were rooted in the practice of surveying, valuation, and sale of parcels of land for cultivation and profit, usually via loans against the valuation of the land (1776 Byres Map, Table 2). This economic system of plantation agriculture in the 18th century British West Indies "rested on a complex and permanent system of borrowed capital, to finance the establishment of plantations and short-term loans to finance the year-on-year running costs, the resultant debts being serviced out of the profits on each year's crop" (Murdoch 1984, p. 569). Although land sale of any one plot was initially limited to lots of around 50 to 100 acres, this was easily circumvented by some purchasers when early 18th century defaulters were forced to resell 


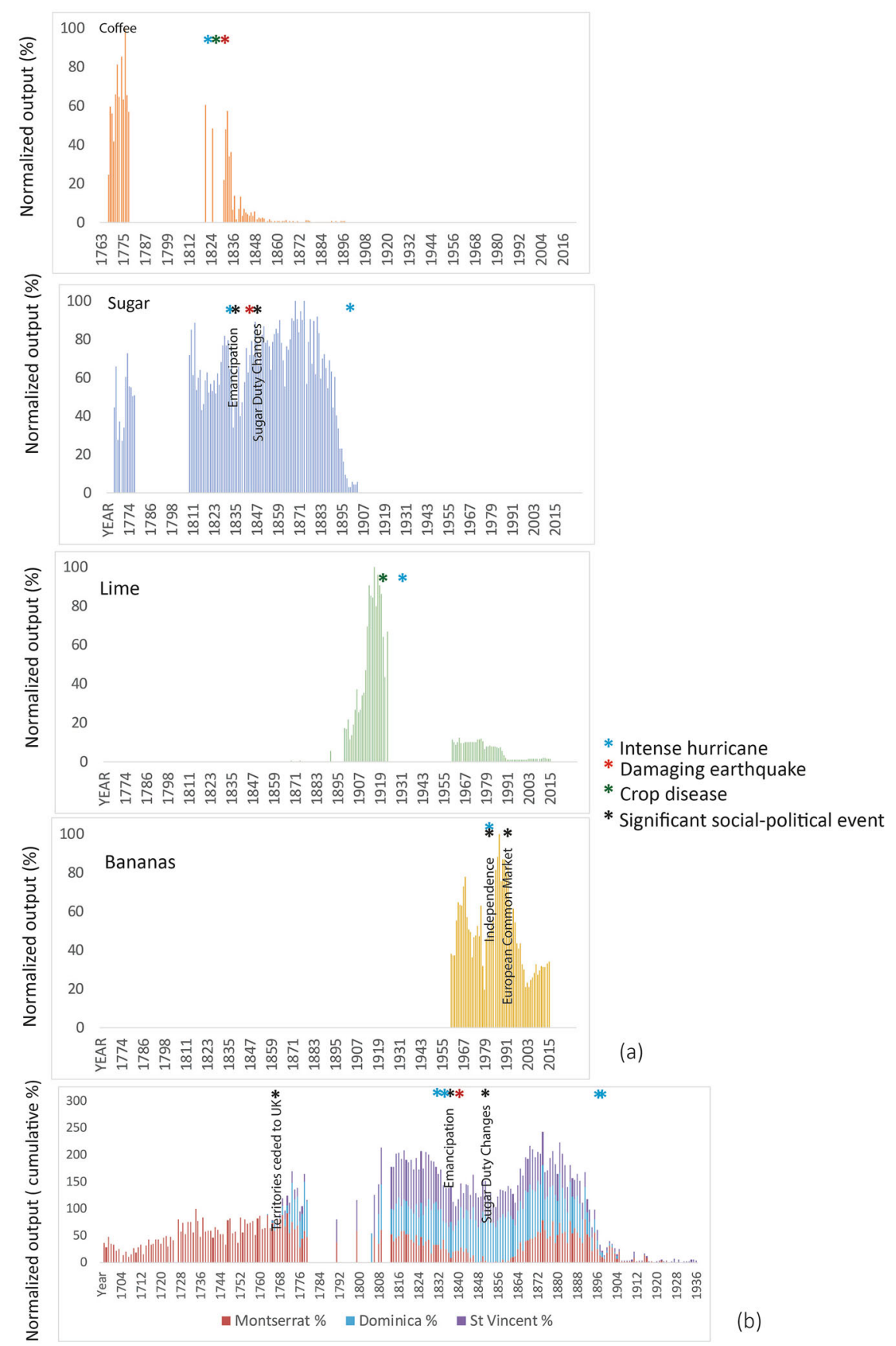

Fig. 2 a The boom and bust of coffee, sugar, lime, and banana production in Dominica, 1763-2016. b Disaster impacts on sugar export crops in three Eastern Caribbean volcanic islands, 1700-1937. In a values are normalized against the year of peak productivity for each crop. Conversions have been used for lime outputs as follows: lime was exported in three main products at varying times-raw and concentrated lime juice, citric acid, and lime essence. Until 1892 reporting discovered focused on the lime juice. From 1900 lime was reported as its total export value across the three products. In the FAO reporting (FAOSTAT 2019) it is declared as tons. Thus a conversion was applied using the reported volume of juice and value equivalency reported in Hamilton (1894). A conversion in this volume of around 1 gallon of concentrated juice per barrel of limes was used to determine the no. of barrels that this was equivalent to in $1892(33,148)$. In 1892 both the value and the amount (liquid mass) were reported. Using a conversion of approximately 3 bushels per barrel and a registered mass of limes as $80 \mathrm{lb}$ in one bushel then this was converted to $\sim 4000$ tons. Thus the 1961 to 2016 data were normalized to this value to produce some equivalency with the earlier data. For values reported in 1870-1875 these were also normalized to the 1892 value suggesting these yields were $<5 \%$ of the peak production value. Cocoa export values were reported until 1896 (same sources) and show an increase in the 1880s and 1890s. But as these are not fully reported, so they are not reproduced here. Data gaps during the Wars between the French and British (1776-1815) represent lack of recording rather than lack of crops. In $\mathbf{b}$ values are normalized against the year of peak productivity (as value in pounds, sterling) for each island. Sources (a) Trouillot (1988, Chapter 3), Naftel (1898), Hamilton (1894), Watts (1927), FAOSTAT (2019), Deer (1950); (b) All data from Deer (1950) 
their land (Welch 1968). Later, this arrangement created little incentive to quit the land permanently and thus repay accumulated debts or to contribute to local taxes once indebted.

There were, nonetheless, local and colonial efforts to address these issues of weak crop diversification and monopolies of land ownership. The Governor of Dominica, J. R. Longden, exhorted the island's Assembly in 1865 to help secure land for the "peasantry" for cultivating exports. A few decades later the Botanic Station in Roseau started operating as a distribution center for plant species, increasingly used by agricultural laborers. An instructor trained by the Kew Botanic Gardens in London provided information on new techniques and practices through the Dominica Agricultural School, which opened in 1900, and it quickly had an effect, enabling small ventures to flourish. However, throughout this period, existing landowners remained wary of ceding land to laborers. Thus, proposals to promote diversification were often superseded by a desire to attract further "capitalists and intending colonists" (Naftel 1898) and the lure of profitability from an individual crop that was attractive to external markets. As a result, the promotion of the monoculture model prevailed until the end of Dominica's colonial period, justified through reference to examples of its success in other (larger) Caribbean islands (Morris 1897), and partially driven by the local tensions around land tenure and the need for capital for infrastructural development as well as crop diversification (see next section).

The outcome of insufficient investment in development and a weak economy was further highlighted in reports commissioned in 1927, 1939, and 1947, with the conclusion that smallholders should be allowed to contribute to the "banana economy" justified by preferential external markets and high levels of profitability at that time (Orde Browne 1939; West India Royal Commission 1945).

\subsubsection{Lack of Investment in Road Infrastructure}

Roseau has been the main settlement since before colonial times when it was the seat of the Kalinago chief of leeward Dominica (Honychurch 1995). Early British development focused on the creation of Portsmouth, with a natural harbor, as a capital but these plans were largely unrealized because low-lying shore grounds were also a natural breeding area for mosquitoes and associated diseases. Further coastal development elsewhere was encouraged by the creation of free lots for poor planters in the late 18th century (also providing a ready militia for future defense). In Dominica, the initial sale of land should have created $£ 326,022$ of revenue by 1773 , but managerial incompetence and defaulted payments meant that less was realized (Murdoch 1984). Some of this money was used to begin an interior road in 1768 and 1769, and some $£ 100,000$ were spent on fortifications as tensions remained high with the French in the late 18th and early 19th centuries (Honychurch 1995). The circular problem of a lack of agricultural development (see previous section) and hence lack of infrastructural development, was driven by a lack of profit, and the implementation of unpopular tax regimes to try and ensure that this investment happened. Unpaid debt from initial land sales rapidly spiraled into rancor, and led to further debt and uncertainty around obligations for infrastructural development and repayments, accentuated by asset and income losses due to hazards and disease. Many plots were completely inaccessible, with investors who purchased them required to construct roads to access their estates. The result was that most estates developed along the coastal strip, while plots in the interior remained inaccessible and undeveloped (Honychurch 1995). By 1893, road networks suitable for wheeled traffic consisted of no more than $40 \mathrm{~km}$ around Roseau, of which $32 \mathrm{~km}$ were unmetalled track (Hamilton 1894; Fig. 1). The lack of roads separated smallholders from markets in Roseau, and villages were obliged to operate largely self-sufficiently, further encouraging coastal development.

During the 19th century, investment in roads and infrastructure generally remained low as the British Government attempted to ensure the colony was costneutral to it in economic terms. A series of unpopular taxes attempted to raise revenue for infrastructure in the mid19th century. Predicated on anticipated land values, these fell disproportionately on the poor, without delivering significant investment in road expansion. Roseau residents were exempt from the Road Tax, encouraging movement to the margins of the capital (Hamilton 1894). Around the turn of the century two major attempts were made to tackle road infrastructure, with the first started in 1888, financed by $£ 40,000$ in loans and increased taxes. Progress was prevented by the combined influences of incompetent engineering and severe flooding in 1891 (Hamilton 1894). In the early 1900s, the construction of the first 12-mile stage of the trans-insular road (known as the Imperial Road) was completed with a $£ 12,000$ grant from the British government (Honychurch 1995; Fig. 1). The planned route for the road up the Layou valley was changed to allow access to a private estate purchased at the time by a wealthy investor. The revised route was controversial, requiring an additional $300 \mathrm{~m}$ of ascent (Hulme 2000), but the route remains a key road link through the island to the present day. The road opened up a swathe of interior land, resulting in an investment of $£ 40,000$ (according to the papers of H. Hesketh Bell, Governor of the Leeward Islands, 1912-1916) (Hulme 2000). However, the estates largely fell into disrepair during the 1920s due to low productivity and problems paying for maintenance of the 
road (Hulme 2000). These early difficulties point to the importance of not just high impact hazardous events but also the challenges posed by low-grade hazardous activities (heavy rainfall and landslides) in creating and sustaining suitable infrastructure.

The 1950s and 1960s saw a concentrated program of road building to complete the major roads as well as the feeder road network (Fig. 1). These feeder roads allowed the Crown Lands in the interior to be accessed and sold to smallholders for banana cultivation. The trans-insular road linking the east and west coasts was completed in 1956, and a road linking the main urban centers of Roseau and Portsmouth was opened in 1972 (Honychurch 1995), financed initially by the Colonial Development and Welfare Office. Infrastructure upgrades have unlocked the agricultural potential of the island to small-scale farmers, but much of this expansion occurred during a period of minimal storm activity, so roads were not built to withstand hurricane impacts. The cost of maintaining these roads in the face of more frequent tropical storms and hurricanes in recent years has been a considerable challenge.

\subsection{Consequences of Exposure to Hazards}

Historical factors have exacerbated the exposure of people, livelihood assets, and infrastructure to hazard impacts. This section discusses how land tenure patterns have created spatial marginalization of the poorer sections of society to hazardous locations, and how badly situated critical infrastructure has resulted in high levels of exposure.

\subsubsection{Changing Knowledge of Hazard Environment}

A critical first step in reducing the physical accumulation of risk is producing knowledge of likely risks and their impacts. Such knowledge is built upon recognizing patterns in hazardous activities at different temporal and spatial scales. The first scale is the changing conditions that may signal hazardous events over coming hours or days, and the second is the recognition of seasonal or even decadal changes in likelihood of hazard occurrence. Phenomena may be recognized or anticipated at differing spatial scales-for example a localized association of unstable slopes or flooding with intense rainfall; or the knowledge that intense earthquake or hurricane impacts may be widely felt; or the recognition of particular geographic areas less prone to particular hazardous phenomena. In this analysis we are not so much concerned with the historical evolution of the understanding of causal mechanisms behind hazardous phenomena, but rather we focus on historical changes in the recognition of patterns in hazards and impacts, and the extent to which this may have helped communities and decision makers to reduce exposure to risk from physical hazards (referred to as "effective hazard knowledge").

There is archaeological evidence (Burke and Lovell 2000; Honychurch 1995) and some historical evidence that the Kalinago lived in dispersed, relatively small settlements across the island, and each settlement had a relatively small sphere of influence on nearby land used for subsistence farming. Schwartz (2015) and Mulcahy (2008) have argued that this dispersed pattern of settlements also distributed the collective impacts of any one storm, and that land use in coastal areas particularly prone to storm surge was restricted. These practices were mirrored by early colonial settlers and smallholders (Schwartz 2015; Honychurch 2017).

Evidence indicates that there was good indigenous understanding of storm seasonality, and of key warning signs of the imminent arrival of a hurricane-drop of wind, changed animal behavior, and unusual aural phenomena around the moon (Mulcahy 2008; Schwartz 2015). Descriptions of early European encounters with these populations suggest these warning signs were taken seriously and were also adopted by the early modern colonists. While on some occasions interpretation of these "signs" may have created false alarms, their recognition encourages mitigation against storm impacts on the time scale of a few hours and long-term adaptations in terms of agricultural practice. However, early colonists introduced a different system of land ownership, demarcated and improved land by cutting down trees, creating fences, and building westernized housing structures, which rapidly increased vulnerability of individuals and assets to storms. But by the early 18 th century significant adaptations in building styles were already recognizable, creating more resilience to hurricanes, reducing the impacts of earthquakes and improving ventilation, thus reducing the potential to incubate disease (Mulcahy 2008).

The use of indigenous knowledge- "ignorant country people and barbarous nations, are better observers of times and seasons, and draw better rules from them, than more civilized and reasoning people, for they rely more on experience than theories," Captain Langfords Observations in Mulcahy (2008, p. 54)—and a relatively well-connected regional trading network quickly led to the recognition of the variety of hazards to be confronted on the island, particularly drought, rain storms, hurricanes, and earthquakes. Regionally, there was a recognition of a geographic distribution of the likelihood of hurricane events (Schwartz 2015); short-time and long-time forecasting was incorporated into trading and military patterns and behavior. As emphasized by Mulcahy (2008, p. 34), by the end of the 17th century "colonists no longer viewed hurricanes 'strange' and 'unusual' but saw them as routine and expected," with a well-defined seasonality. This 
knowledge could have informed mitigative or adaptive strategies even in the absence of a detailed understanding of the causes of such hazards and of accurate modern forecasting.

However, effective knowledge of some other hazards was more patchy, including hazards with longer recurrence intervals (for example, earthquakes and volcanic eruptions), and fewer warning signals (earthquakes). Knowledge of these phenomena improved as documentation and means of communication increased through the 19th and 20th centuries (so learning from one area might be applied elsewhere) and is one area where the "regionalized" colonial governance may have been a useful means by which to achieve this. Extensive hazards such as droughts and landslides were also remarked upon but generally considered as an additional nuisance in realizing infrastructural projects or sustaining productivity (see Sect. 4.1.2).

Hazard exposure may also have been influenced by natural variability in some phenomena. Fifty- to seventyyear cycles in hurricane activity in the Caribbean have been recognized, associated with multi-decadal variations in North Atlantic Sea Surface Temperature (Chenoweth and Divine 2008, 2012) and with further variance imposed on shorter time scales. These translate into periods of lower hazard occurrence and activity across the region and on any one island, on the time scales in some instances of a human lifetime and in many cases at least of a political cycle (see Sect. 4.1.2).

Effective hazard knowledge, which had the potential to be deployed to reduce risk exposure, was available and shared at least from the 16th century onwards, improving through the 18th and 19th centuries. But in the Caribbean, where use of the land and sea became dominated by constant market forces, the temptation to ignore mitigative or adaptive strategies for such discrete and intermittent impacts of hazards as indicated here was perhaps stronger.

\subsubsection{Restricted Access to Land}

After 1763, with the parceling of land following the Byres survey, the twin demands of trade and security played a stronger role in settlement location with a need to create infrastructure such as roads and fortifications. The restrictions on land use and availability of small holdings for successive generations described here have not only made the economy more susceptible to natural hazards, it has also caused much of the population to be concentrated in locations with heightened exposure despite knowledge of that potential exposure. In complex ways this process is tied to the legacy of emancipation.

In 1838, when freedom from slavery was granted, the colonial government pursued an intentional policy to keep "former slaves" from owning land. In 1836, Lord Glenelg,
Secretary of State for the Colonies had sought to maintain levels of labor on colonial estates in order to ensure economic stability for Britain. An effective way of ensuring this was to financially and structurally "impede" the acquisition of land by free slaves, and therefore force them into estate labor for survival (Honychurch 2017). In the late 18th century the decision to sell land to the highest bidder above a set minimum price kept most people as landless laborers (Trouillot 1988). Although the colonial poor were somewhat accommodated, landless black laborers were caught in a vicious circle until as late as 1945, as purchase of less than 40 acres of land was not permitted, and wages were kept low. In the 1950s, Crown Lands were sold to smallholders, and were located inland from the colonial estates (Honychurch 1995).

After emancipation, landless former slaves who wished to grow their own provisions had no choice but to settle illegally where they found unoccupied land. Illegal settlement was particularly concentrated in coastal areas within the King's Three Chains (a 66 yard wide coastal strip) defined by John Byres in the 1760s.

Some estate owners with land near the King's Three Chains attempted to eject "squatters," but these attempts often revealed a lack of clarity over estate boundaries and land tenure, and in some instances, estates tacitly endorsed these processes. As a result, laborers remained on land where no eviction action was taken, which explains some of the crowded beachfront communities on the west coast of Dominica (Honychurch 2017). Many of these beachfront communities are today exposed to coastal hazards. For example, Pointe Michel was one of the hardest hit communities by Hurricane Maria in 2017.

\subsubsection{Expansion of the Road Network into Hazardous Places}

Dominica's public infrastructure is highly exposed to natural hazards and became increasingly so during the 20th century as infrastructure expanded to serve communities along the coast and in ravines as urban settlements expanded. The origin of this high exposure lies in the colonial partitioning of land and the post-emancipation settlement described above, and investments in infrastructure have followed these settlement patterns. As a housing officer in the Government of Dominica ${ }^{1}$ explained:

Runaway slaves moved away from the plantation and set up shop in these mountain top areas. Over the years, generations and people continued to reside there and Governments over the years have gone in and brought in roads and other amenities.

\footnotetext{
${ }^{1}$ Interview took place in Roseau, Dominica on 15 March 2017.
} 
The road network (Fig. 1) expanded rapidly between 1950 and 2018 including the completion of the trans-insular road, the road linking the two main settlements of Roseau and Portsmouth and subsequent creation of feeder roads took place to service the smallholders participating in banana cultivation. The road network consists of $566 \mathrm{~km}$ of main and secondary roads, $338 \mathrm{~km}$ of feeder roads, and 200 bridges. The roads traverse unavoidably steep landslideprone slopes and flood-prone river crossings in order to serve communities strung out along the original King's Three Chains settled by emancipated slaves. These feeder roads place a substantial burden on the government in terms of both general maintenance and repair following both extreme and annual weather events. In 2009, a road condition assessment showed that about $24 \%$ of the main roads and $90 \%$ of the secondary, urban, and feeder roads were categorized as in poor or bad condition. In 2015, Tropical Storm Erika damaged or destroyed $40 \%$ of roads and $50 \%$ of bridges (Government of the Commonwealth of Dominica 2015).

The expansion of the road network coincided with a relatively quiet period in terms of numbers of hurricanes, so ensuring structures could withstand the high wind speeds and flooding associated with high-impact events may not have been considered a high priority at that time (Benson et al. 2001). Limited grant funding and a major infrastructure deficit may have incentivized a least-cost approach to road design and construction, which has left Dominica with a legacy of rapidly deteriorating roads. Roseau, as the capital, has become a significant port, despite exposure to wave action during storms. At least six jetties near Roseau have existed at various times, and, in turn, been destroyed by hurricanes (Honychurch 1995). Dominica's first and only deepwater port at Woodbridge Bay, north of Roseau, opened in 1978. In 1979, this facility was extensively damaged by Hurricane David, with a rehabilitation cost estimated at $41 \%$ of the total original project cost. Strengthening of part of the jetty against swells in 1996 was vindicated following Hurricane Lenny in 1999, which damaged only the unreinforced part of the jetty deck. The port continued to operate following Lenny, providing the only lifeline berthing facility (Benson et al. 2001).

Historical decision-making processes have therefore exacerbated exposure to hazards in several important ways. Firstly, the development of settlements in hazard-prone locations can be traced back to colonial times and particularly emancipation, when settlement in highly exposed coastal locations and marginal Crown Lands occurred. Secondly, some of the poorest and most marginal settlements are relatively isolated and particularly vulnerable to disasters. Thirdly, the late development of roads, air- and seaports during the 1950 s to the 1970 s, a period of infrequent hurricanes, may have disincentivized designs capable of withstanding the type of extreme events seen in the latter part of the 20th and early 21 st centuries.

\subsection{Disaster Response, Relief, and Governance}

Historical practices of response and relief over time have also acted to create deep-rooted structures and expectations that resonate today. Under colonial rule, island administrators and communities on Dominica responded to disasters by requesting assistance from the Crown Estate in Britain, which in turn, provided ad hoc grants and loans that drew on the already complex system of borrowed capital with which the colony was established by the British Government. Although intended to facilitate the economic and social recovery of both private landowners and public infrastructure, these actions were also rooted in the primary function of the British Empire at the time, that is maximizing profit for the UK while minimizing debt burden. Loans after the 1834 hurricane and the 1843 earthquake, for example, involved lengthy correspondence (through a hierarchy of governance layers), usually required repayment, and frequently accrued substantial interest. These loans were not distributed equitably, and repayment was often renegotiated, sometimes formally and sometimes on an ad hoc basis. This led to an emphasis on backward looking repayment and recovery in response to past disaster, rather than on the creation of incentives to invest, learn, and prepare for future problems, despite over 100 years of reporting and analysis that advocated for alternative pathways and good hazard knowledge (Hamilton 1894; West India Royal Commission 1898, 1945; Benson et al. 2001).

Moreover, loan systems were also frequently homogenized under common administrative pathways for several islands. Thus islands recovering from the impacts of a hazardous event could find themselves with similar terms and loan agreements to an island dealing with the aftereffects of, for example, a slave rebellion, arguing retrospectively for the specific nature of their need. A second outcome from this was the practice of less formal pathways to economic recovery via diaspora, absentee landlords, and "in kind" or actual support from neighboring islands with some resources to spare.

\subsubsection{A Short-Sighted Response to the 1834 Hurricane}

This amplification of disaster impacts because of complex administrative and financial responses is best illustrated through a detailed example of the 1834 hurricane, for which an estimated $£ 291,500$ of losses were incurred (House of Commons 1855). Responses in the decades following this event were both bureaucratic and ineffective in terms of creating a self-sufficient recovery, failing to 
provide a spur to sustainable economic growth and no incentive to break with the monocultural model of production. Initial response and requests after the 1834 hurricane focused on alleviating civil expenditure and providing tax breaks (the initial 1835 Relief Bill allowed duty free imports of lumber, shingles, flour, beef, pork, and fish for a few months). The island was granted $£ 80,000$ (by session 5\&6 Will.4, c51; House of Commons 1855) and of this, $£ 10,000$ were loaned for public services and a total of $£ 66,950$ were loaned to estate proprietors in the form of 64 individual loans. However, this came from a reallocation of the West Indies Loan Act (House of Commons 1832), where $£ 1$ million had been allocated to Jamaica, Barbados, St. Vincent, and St. Lucia for hurricane relief and dealing with "insurrection." These loans, provided through the newly formed West Indies Relief Commission, were at lower interest rates (3\% originally), secured by mortgages, with interest payments charged against future estate revenue, mirroring commercial practice in the private credit market (Smith 2012). Little direct support was given to slaves or anyone of mixed race, but local government agents received grant-in-aid at low cost for the benefit of the general population to coordinate supplies of shelter, food, and clothing (Smith 2012).

Public debts and interest, and private interest accruing were then variably repaid until a damaging earthquake in 1843 generated claims of $£ 8000-£ 10,000$ in damage to the whole island. The Subsequent Relief Act offered further loans up to a total value of $£ 50,000$ to Dominica for a three-year period at $4 \%$ interest. This setback, exacerbated by the 1846 Sugar Duties Act, which equalized import duties on sugar from British colonies (West Indian colonies had been favored by lower sugar import duties since 1814) meant that loans were no longer repaid and debts accumulated. By 1855, outstanding public loans were calculated at $£ 7002$, while loans on estates now totaled $£ 92,352$. Further amendments to the Relief Act were created in 1848,1860 , and 1867, to accommodate differing repayment terms and incorporate the payback on further loans (Hamilton 1894). Arguments for the particularity of Dominica centered on the impacts on the coffee industry, amplified by longer disease and regrowth time for coffee bushes (and cocoa trees) in comparison to sugarcane (House of Commons 1855). Detailed correspondence reveals the compounding issues of increasing agricultural and freight costs, the financial impacts of troop withdrawal on local markets and the readjustment of sugar. By 1878 , the West India Relief Commission was wound up and there was a remission of most unpaid loans. The decision was taken that some loans could not be repaid because payment depended on profit from plantations, which had been substantially reduced. Eventually, with the 1879 West India Loans Bill, all private (estate owners') outstanding loans were written off, and the last payment for the outstanding public services loan ( $£ 1527$ of the $£ 10,000$ advanced) was in 1880 . Attention then returned to the means by which Dominica could once again become profitable (Hamilton 1894).

The balance of loans and grants over time show a consistent pattern of requests for financial assistance from the Lieutenant-Governor of the island followed by inability to make repayments, patterns that are repeated in analyses through the 20th century (West India Royal Commission 1945; Benson et al. 2001). The time scale of loan repayment often exceeds the time scale over which the next environmental or social calamity occurred. Despite the geographical, cultural, and historical diversity of the Caribbean islands, the approaches to requesting repayment of loans by the British Government were similar and uniform. Islands that were not performing well in terms of exports and profits were managed by following the pattern of colonial development established on others. But island governors and British-commissioned reviews argued for recognition of the particularities of individual islands. The legacy of unpaid loans (despite remission of most by the early 1880s) continued to be felt, through difficulties in reestablishing profitable agricultural outputs and fit-forpurpose infrastructure at the end of the century and beyond, as discussed in previous sections. Deeply entrenched patterns of post hoc requests for remission from debt and hardship set in, rather than forward looking arguments for radical change.

\subsubsection{The Post-Colonial Disaster Management Legacy}

After independence, a more proactive, cyclical approach to preparing for hurricanes and storms began to emerge in Dominica. The government set up a National Office of Disaster Management (ODM) within the Ministry of Communications, Works and Housing (MCWH) following the devastating impact of Hurricanes David and Frederick in 1979. In 1996, a National Disaster Plan was finally published, with a detailed set of actions and responsibilities for disaster preparedness and emergency response. But this plan did not directly address the need to reduce levels of exposure and economic vulnerability over the longer term-and despite frequent disasters and devastating impacts (including Hurricane Allen in 1980, Hugo in 1989, three tropical storms in 1995, and Hurricane Lenny in 1999), little thought was given in post-disaster response and recovery to reducing future risk. ${ }^{2}$

\footnotetext{
2 The National Disaster Plan issued in 1996 and updated in 2001 describes recovery as a phase of the disaster management cycle and establishes an Economic Stability Task Force to ensure plans are made for the recovery of the economy, but there are no regulations or guidance on how those plans should be developed.
} 
The Dominica government responded to frequent disasters in the 1980s and 1990s by reallocating parts of the budget to pay for relief and rehabilitation, which alongside the damage to banana crops and loss of export earnings, intensified budgetary pressures that were already severe due to oil price rises and other shocks (Benson et al. 2001).

Dominica, to this day, continues to be an agrarian-based economy with a weak transport infrastructure network that is highly vulnerable to hurricanes and other hazards. Decisions about economic development over the last 40 years have largely ignored the impacts of disasters and the need to diversify into more resilient productive activities. Some diversification has occurred reducing reliance on one expert crop, but this has occurred mainly within the agriculture sector, and there has been little deliberate effort to reduce the overall hazard vulnerability of Dominica's economy (Benson et al. 2001).

Dominica continues to suffer from the underinvestment in road infrastructure during colonial era. An important increase in capital expenditure in the 1980s following Hurricane David was needed to rehabilitate roads, but also because the country's infrastructure was already in a poor condition due to years of inadequate maintenance and low investment. This increase in expenditure deepened levels of debt.

Dominica is heavily reliant on external aid when disasters occur, and this creates inefficiencies in disaster response and recovery. Delays in aid disbursement due to limited local administrative capacity and inability to meet funding requirements severely affected the government's capacity to respond effectively (Benson et al. 2001).

After independence, several reports and tailored advice for reducing disaster risk in Dominica were commissioned by international agencies and produced by external consultants. These focus on the specific needs of the island and provide concrete sets of recommendations around using risk information in development planning so as to focus investment on more resilient infrastructure and the diversification out of agriculture (see, for example, Benson et al. 2001), but these had little influence on disaster policy in Dominica until Tropical Storm Erika in 2015. After a period of relative calm, Erika caused significant damage, killing 30 people and making it the nation's worst disaster since Hurricane David. Dominica saw an influx of international assistance, but also detailed impact studies with far-reaching recommendations. ${ }^{3}$ This generated some political interest, at least in the immediate aftermath of the storm, to take action to reduce disaster impacts in the

\footnotetext{
${ }^{3}$ See, for example, the rapid damage and impact assessment conducted by a World Bank mission in Dominica: "Rapid Damage and Impact Assessment Tropical Storm Erika - August 27, 2015, A Report by the Government of the Commonwealth of Dominica." September 25, 2015.
}

future. But recovery was slow, and two years later Dominica was devastated by Hurricane Maria, a category 5 hurricane, which caused total losses of approximately USD 930.9 million, and undid much of the rehabilitation effort following Tropical Storm Erika. With all eyes on the Caribbean, the Prime Minister of Dominica, Roosevelt Skerrit, committed his country to becoming "the world's first climate resilient nation." Achieving this will require serious reflection on the appropriateness of current land use and the resilience of agricultural practices and infrastructure, and will need a new nationally owned, investmentdriven recovery model (Wilkinson 2018).

\section{Conclusions}

This article presents an analysis of historical social, economic, and political processes that have had overwhelming implications for Dominica's development trajectory. Notwithstanding the severe challenges posed by the island's geographical location, topography, and exposure to multiple forms of hazard, lessons can be drawn from an historical analysis to inform recovery planning and help manage risks more effectively in the future.

This article underscores the role that seemingly unrelated social, economic, and political processes can play in generating disaster risk for decades to come. In Dominica, this can be seen in decisions taken at the beginning of British colonial rule. These include: the division and sale of land; decisions about labor and land use at the time of emancipation; coastal zoning and the establishment of the King's Three Chains; road construction; and the pursuit of an export-led economic development model, based around large plantations with the aim of generating economic surplus from the colonies (with the largely unfulfilled expectation that these profits would lead to private investment in infrastructure). All these decisions, actions, and policies had serious implications for the local economy and the freed slave populations at the time and set Dominica on a trajectory of accumulating hazard exposure and high economic vulnerability.

Natural hazards have played a dominant role in the island's development or lack of it, despite good knowledge of the occurrence and severity of many of these hazards. Severe hazard events have occurred with such frequency (and often coinciding) that economic recovery has been repeatedly set back, yet little attention has been paid in economic policy to the potential impacts of natural hazards. An important but previously less studied impact is the attritional impact of hazards such as landslides and slope instability that increase year-to-year costs of creating or sustaining infrastructure and make recovery from intensive events harder. These are particularly acute on the 
mountainous "volcanic islands." When disasters hit Dominica, landowners took on high levels of debt to replace lost assets, but when crops failed to recover, loans could not be repaid, and indebtedness increased, deepening their vulnerability to further shocks, and rendering the economic model less viable. This pattern of disasters devastating crops and reducing exports, followed by a colonial response that further undermined development, has been repeated without prompting any changes in agricultural policies or post-disaster aid. Despite the fact that the colonial export-led model of development was inappropriate for Dominica, the model was not modified. It was assumed that the same things would work for all Caribbean islands despite critical differences in physical geography and timing of economic development that would suggest otherwise. After independence, the exportled model based principally on agricultural exports continued (albeit with further land division and smaller production units), with the addition of tourism and a small financial services sector. Dominica has been less successful than many other Caribbean islands in these economic activities, largely due to limited tourist infrastructure (Boxill and Severin 2004).

Yet, lessons can be learned from disasters, and "mistakes" avoided if the right questions are asked about who was affected and why recovery processes were slower than anticipated. Concrete policy advice for the present and future can be deduced from structural knowledge about the past (Schenk 2015). In the aftermath of Hurricane Maria, the government and the private sector face the inevitable pressures of pursuing rapid recovery, yet politicians have also called for a reduction in longer-term disaster risk, and Dominica has set the ambition to become the first climate resilient nation. This requires consideration of not only recent events but the cumulative impacts of past disasters on people and economic development in Dominica. A proactive, longer-term approach is needed, as one local government commissioner ${ }^{4}$ admitted:

We have to take a more proactive global kind of approach to really understand Dominica as a whole: what are the risk factors and the level of exposure; and what are the best policy decisions to really address a more long-term solution? The reality is, as a small island developing state, you really have major economic challenges... Sometimes the easier way out is to be reactive. Something happens you respond; but it's not very sustainable. So, you respond to [hurricane] David....and [hurricane] Lenny comes... and as you responded to Lenny, you get an Erika.

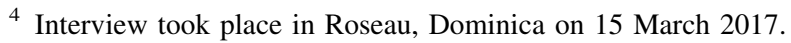

New planning instruments are needed to support development away from rivers and coasts and to include local populations in these plans. Today, Dominica's low-income families continue to live in informal settlements along what was Crown Land, in river valleys and on the margins of urban centers, highly exposed to floods and erosion, and easily cut off by damage to the one coastal road linking them together. These settlements were severely impacted by Tropical Storm Erika and Hurricane Maria, with many houses being completely destroyed as a result of river flooding (Government of the Commonwealth of Dominica 2017).

An important finding from this study is that decisions about access to land, and ownership patterns that marginalize the poor and accentuate inequalities, also create disaster risk and constrain development. They are as critical as the decisions and investments taken intentionally to manage risk - such as the development of early warning systems and preparedness plans. Recognizing these historical drivers of risk is key if Dominica is to avoid taking decisions in the future that will undermine and compromise efforts to build the island's resilience.

This situation is not unique to Dominica, and a similar analysis of the precise historical factors that have shaped development would be beneficial for other Caribbean islands and SIDS with colonial histories. A larger and broader study would enable comparisons to be analyzed, and enable patterns - if they are present - to emerge.

Disaster research rarely considers past events or decisions taken further back than the very recent past. This can result in superficial sets of recommendations that fail to recognize the deep structural problems, and their ongoing consequences, that need to be understood and addressed to reduce disaster risk effectively and build future resilience.

Acknowledgements This study arose from and was supported by the UK Global Challenges Research Fund grant NE/P015719/1. Strengthening Resilience in Volcanic Areas (STREVA NE/J020052/ 1) and a University of East Anglia Global Challenges Research Fund (UEA GCRF) Award also supported further fieldwork and investigator time. Special thanks are due to the National Documentation Centre in Roseau, Dominica and the National Archives and the British Library in London, UK, for their assistance with archival material, and especially to the communities and stakeholders in Dominica who contributed their experience and perspectives to the research. The constructive comments from two anonymous reviewers and Associate Editor Ilan Kelman considerably improved this manuscript.

Open Access This article is distributed under the terms of the Creative Commons Attribution 4.0 International License (http://crea tivecommons.org/licenses/by/4.0/), which permits unrestricted use, distribution, and reproduction in any medium, provided you give appropriate credit to the original author(s) and the source, provide a link to the Creative Commons license, and indicate if changes were made. 


\section{References}

ACAPS (Norwegian Assessment Capacities Project). 2018. ACAPS disaster profile: Dominica. https://www.acaps.org/sites/acaps/ files/products/files/20180131_acaps_disaster_profile_dominica_ v2.pdf. Accessed 30 Jan 2018.

Bankoff, G., G. Frerks, and D. Hilhorst. 2004. Mapping vulnerability: Disasters, development and people. London: Earthscan.

Barker, D. 1993. Dualism and disasters on a tropical island: Constraints on agricultural development in Jamaica. Tijdschrift voor Economische en Sociale Geografie 84(5): 332-340.

Benson, C., E. Clay, F.V. Michael, and A.W. Robertson. 2001. Dominica: Natural disasters and economic development in a small island state. Washington, DC: World Bank.

Bishop, M.L. 2013. The political economy of Caribbean development. Houndmills, UK: Palgrave Macmillan.

Boxill, I., and F.O. Severin. 2004. An exploratory study of tourism development and its impact on the Caribs of Dominica. International Journal of Tourism of Hospitality and Tourism Administration 5(1): 1-27.

Breton, R. 1647. Island of Guadeloupe relations (Relations de l'Îsle de la Guadeloupe). Basse-Terre,France: Society of the history of Guadeloupe (Société de la histoire de Guadeloupe).

Burke, W., and W.G. Lovell. 2000. Demise at the edge of empire: Native depopulation in Dominica, 1493-1647. Yearbook, Conference of Latin Americanist Geographers 26: 1-16.

Byres, J. 1776. Plan of the island of Dominica laid down by actual survey under the direction of the Honorable the Commissioners for the Sale of Lands in the Ceded Islands. London: S. Hooper. https://www.bl.uk/collection-items/plan-of-the-island-of-domin ica. Accessed 19 Mar 2019.

Chenoweth, M., and D. Devine. 2008. A document-based 318-year record of tropical cyclones in the Lesser Antilles, 1690-2007. Geochemistry, Geophysics, Geosystems 9(8). https://doi.org/10. 1029/2008gc002066.

Chenoweth, M., and D. Devine. 2012. Tropical cyclones in the Lesser Antilles: Descriptive statistics and historical variability in cyclone energy, 1638-2009. Climatic Change 113(3-4): 583-598.

Collins, A.E. 2009. Disaster and development. Abingdon, UK: Routledge.

Deer, N. 1950. The history of sugar. London and Beccles, UK: Chapman and Hall.

Dookeran, W. 2015. Crisis and promise in the Caribbean: Politics and convergence. London: Routledge.

FAOSTAT (Food and Agricultural Organisation of the United Nations, Statistics Division). 2019. Online database. http:// www.fao.org/faostat/en/\#home. Accessed 15 Dec 2017.

Garnier, E., and J. Desarthe. 2013. Cyclones and societies in the Mascarene Islands 17th-20th centuries. American Journal of Climate Change 2: 1-13.

Government of the Commonwealth of Dominica. 2015. Rapid damage and impact assessment Tropical Storm Erika. http:// documents.worldbank.org/curated/en/142861467995411564/ Dominica-Rapid-damage-and-impact-assessment-tropicalstorm-Erika. Accessed 27 Aug 2017.

Government of the Commonwealth of Dominica. 2017. Post-disaster needs assessment Hurricane Maria. https://reliefweb.int/sites/ reliefweb.int/files/resources/dominica-pdna-maria.pdf. Accessed 18 Dec 2017.

Hamilton, R. 1894. Report of the Royal Commission to inquire into the condition and affairs of the island of Dominica and correspondence relating thereto. London: Eyre and Spottiswoode, on behalf of Her Majesty's Stationery Office.
Hewitt, K. 1983. Interpretations of calamity: From the viewpoint of human ecology. Boston: Allen and Unwin.

Honychurch, L. 1995. The Dominica story: A history of the Island. London: Macmillan.

Honychurch, L. 2017. In the forests of freedom: The fighting Maroons of Dominica. London: Papillote Press.

House of Commons. 1815. Papers relating to insurrection at Dominica and conduct of Governor Ainslie, 1812-14. House of Commons Sessional Papers, 303.

House of Commons. 1832. Bill to enable H.M. to direct Issue Exchequer Bills (for Relief of W. India Colonies). Bills and Acts. 627 IV.661 Vol 4. House of Commons Sessional Papers.

House of Commons. 1855. Correspondence between W. India Colonies, Treasury, Colonial Office, or Coms. for W. India Island relief fund, relative to estates in W. Indies indebted to government for advances for losses in hurricanes of 1831-32. House of Commons Papers, 159470 Vol XXVII.

Hulme, M. 2000. Islands and roads: Hesketh Bell, Jean Rhys, and Dominica's Imperial Road. The Jean Rhys Review 11(2): 23-51.

Jamaica. 1950. West Indian census 1946: Part A General report. Central Bureau of Statistics: Kingston.

Lewis J, Kelman I 2010. Places, people and perpetuity: Community capacities in ecologies of catastrophe. ACME: An International Journal for Critical Geographies 9(2): 191-220.

Mandle, J. 1982. Patterns of Caribbean development: An interpretive essay on economic change. London: Routledge.

Morris, D. 1897. Report of the West India Royal Commission with subsidiary report. London: Eyre and Spottiswoode, on behalf of Her Majesty's Stationery Office.

Mulcahy, M. 2008. Hurricanes and society in the Greater British Caribbean 1624-1783. Baltimore and London: Johns Hopkins University Press.

Murdoch, D.H. 1984. Land policy in the eighteenth-century British Empire: The sale of Crown Lands in the Ceded Islands, 1763-1783. The Historical Journal 27(3): 549-574.

Naftel, C.O. 1898. Report on the agricultural capabilities of Dominica. London: Eyre and Spottiswoode, on behalf of Her Majesty's Stationery Office.

Nelson, V. 2010. Dominica's lime industry: Agriculture and identity in the early twentieth century. National Identities 12(3): 219-236.

Nicholls, H.A.A. 1894. West Indian Lime (Citrus Medica, L., var. acida, Brandis.). Bulletin of Miscellaneous Information (Royal Botanic Gardens, Kew) No. 88(Apr): 113-116.

Niddrie, D.L. 1966. Eighteenth-century settlement in the British Caribbean. Transactions of the Institute of British Geographers 40: 67-80.

Oliver-Smith, A., and S.M. Hoffman. 1999. The angry earth: Disaster in anthropological perspective. New York: Routledge.

Orde Browne, G. St. J. 1939. Labour conditions in the West Indies. Report by Major G. St. J. Orde Browne, O.B.E. London: His Majesty's Stationery Office. Parliamentary Paper by Command Cmd. 6070.

Payne, A. 2006. The end of green gold? Comparative development options and strategies in the Eastern Caribbean Banana-Producing Islands. Studies in Comparative International Development 41(3): $25-46$.

Payne, A. 2008. After Bananas: The IMF and the politics of stabilisation and diversification in Dominica. Bulletin of Latin American Research 27(3): 317-332.

Pelling, M. 2003. The vulnerability of cities: Natural disasters and social resilience. London: Earthscan.

Reading, A. 1986. Landslides, heavy rainfalls and hurricanes in Dominica, West Indies. Submitted for the Degree of Doctor of Philosophy at the University of Wales, June 1986. 
Schenk, G.J. 2015. 'Learning from history'? Chances, problems and limits of learning from historical natural disasters. In Cultures and disasters: Understanding cultural framings in disaster risk reduction, ed. F. Krüger, G. Bankoff, T. Cannon, B. Orlowski, and L. Schipper, 72-87. London and New York: Routledge.

Schwartz, S. 2015. Sea of storms: A history of Hurricanes in the Greater Caribbean from Columbus to Katrina. Princeton, NJ: Princeton University Press.

Smith, S.D. 2012. Storm hazard and slavery: The impact of the 1831 Great Caribbean Hurricane on St Vincent. Environment and History 18(1): 97-123.

Thompson, R. 1987. Green gold: Bananas and dependency in the Eastern Caribbean. London: Latin American Bureau.

Trouillot, M.R. 1988. Peasants and Capital: Dominica in the world economy. Baltimore and London: Johns Hopkins University Press.

United Nations. 2017. World population prospects 2017. https://esa. un.org/unpd/wpp/. Accessed 20 Jun 2018.

Watts, F. 1927. Report on the agricultural conditions of Dominica with recommendations for their ameliorations. Antigua: Government Printing Office. (PRO, C.O. 152/398 and Roseau Public Library).
Welch, B. 1968. Population density and emigration in Dominica. The Geographical Journal 134(2): 227-235.

West India Royal Commission. 1897. Parliamentary paper by Command 8655.

West India Royal Commission. 1898. Royal Commission on depression in sugar industry in West Indian Colonies, and their general condition. Parliamentary paper by Command 1898. C8654.

West India Royal Commission. 1945. Dominica report. Parliamentary paper by Command 6607, 6608 and 6174 (Recommendations, dated 1940).

Wilkinson, E. 2018. Towards a more resilient Caribbean after the 2017 hurricanes. Report from roundtable discussions, 30 January 2018. London: Overseas Development Institute (ODI).

Wilkinson, E., E. Lovell, B. Carby, J. Barclay, and R.E. Robertson. 2016. The dilemmas of risk-sensitive development on a small volcanic island. Resources 5(21): 1-20.

Wisner, B., P. Blaikie, T. Cannon, and I. Davis. 2004. At risk: Natural hazards, people's vulnerability and disasters. London and New York: Routledge.

Yankey, B.J. 1969. A study of the situation in agriculture and the problems of small scale farming in Dominica, West Indies. Madison, WI: University of Wisconsin Press. 